\title{
Influence of gas hydrate dissociation on mechanical properties of gas hydrate-bearing sediment
}

\author{
W. Zhang, Q. Li \& Y. Li \\ Research Institute, China National Offshore Oil Corporation, Beijing, China \\ H. Cun \\ Institute of Mechanics, Chinese Academy of Sciences, Beijing, China
}

\begin{abstract}
Gas hydrate dissociation in marine sediments will cause increase of excess pore pressure, loss of soil particle cementation and breakdown of soil structure, which may result in large deformations of the strata and offshore structure foundations. Based on the permafrost and ocean environmental conditions, a high pressure and low temperature apparatus has been self-designed and a series of triaxial tests have been carried out to study the influence of gas hydrate dissociation on mechanical properties of gas hydrate-bearing sediment. The effects of dissociation time, confining pressure and dissociation temperature on the mechanical characteristics of the sediment containing gas hydrates are investigated. Moreover, the mechanical parameters of cohesion and internal friction angle are quantitatively analyzed during hydrate dissociation. This study is important for understanding of the evolution of sediment mechanical properties during hydrate dissociation, for controlling hydrate reservoir stability and project risk.
\end{abstract}

\section{INTRODUCTION}

Gas hydrate is sensitive to environmental changes, such that dissociation of hydrate may occur. It is suggested that gas hydrate dissociation in marine sediment may cause an increase in excess pore pressure, loss of soil particle cementation, and breakdown of soil structure, which may result in geohazards and risks, such as submarine landslides (Field 1990, Kayen \& Lee 1991, Paull et al. 1996, Rothwell et al. 1998, Mienert et al. 2005), sediment slumping (Vogt et al. 1994, Dillon et al. 2001), pockmarks and mud volcanoes (Vogt et al. 1994, 1999, Van Rensbergen et al. 2002, Zuhlsdorff \& Spiess 2004), soft-sediment deformation (Kennett \& Fackler-Adams 2000) and giant hummocks (Davies et al. 1999). In addition, the release of methane from dissociating gas hydrate into the atmosphere may increase greenhouse effect (MacDonald 1990, Nisbet 1990, Dickens et al. 1995, Kennett et al. 2003). Therefore, a quantitative study on the mechanical properties of gas hydrate-bearing sediment related to hydrate dissociation is essential.

Grozic \& Kvalstad (2001) proposed a gas hydrate triaxial testing program. Dissociation of the hydrates was achieved by warming of the specimen under undrained conditions. Test data indicated that hydrate dissociation resulted in an increase in pore pressure corresponding to approximately $10 \%$ reduction in the effective consolidation stress.

Mikami et al. (2006) investigated the dissociation of natural gas hydrate using X-ray CT. By continuously monitoring the discharged gas flows and sample temperatures, it was concluded that gas hydrate dissociated simultaneously both on the exposed surfaces and within the pore spaces of the sample in response to pressure changes.

Zhou et al. (2007) carried out experiments on methane hydrate dissociation by depressurization of quartz sand samples. It was shown that electrical resistance was an excellent indicator for the formation and dissociation of methane hydrate. It was found that electrical resistance increased with hydrate formation and decreased sharply with hydrate dissociation. In comparison to heated water injection, the dissociation rate by depressurization was very low and become lower as the dissociation continued.

Hyodo et al. (2009) performed methane hydrate dissociation tests by increasing the temperature of the specimen and observed increased shear and volumetric strains in the specimen. They concluded that during the hydrate dissociation, the volumetric strain had a dilative tendency irrespective of the effective confining pressure when no shear stresses applied. When shear stresses were applied, shear deformation increased with the observed changes varying according to whether the critical void ratio was reached or not, while the degree of hydrate saturation influenced the amount of volume change.

Zhang et al. (2011) examined the mechanical behaviors of tetrahydrofuran (THF) hydrate sediments of fine sand and Mongolia sand as the skeleton. It was shown that all specimens showed plastic failure 
during dissociation of hydrate leading to the reduction in strength of the sediments. The loss of strength, leading to liquefaction of the sediment, after dissociation, occurred quicker when compared to saturated sand.

As summarized above, understanding the behavior of the mechanical characteristics of gas hydratebearing sediment during dissociation is somewhat lacking. Further studies are required to understand behaviors, such as the measurement and quantitative study of mechanical parameters, the investigation of different influence parameters, the effects of different dissociation conditions, and so on.

In this paper a series of triaxial tests has been carried out to study the mechanical properties and dissociation characteristics of kaolin clays containing methane hydrates, similar to the conditions of permafrost and ocean environmental conditions. The effects of dissociation time, confining pressure and dissociation temperature on the strength and dissociation property of gas hydrate-bearing sediment are investigated. The stress-strain behavior, such as shear strength, cohesion and internal friction angle are quantitatively analyzed during hydrate dissociation process. The present work is important for understanding changes in the mechanical properties of the sediment during hydrate dissociation to ensure hydrate reservoir stability and reduce project risk.

\section{EXPERIMENTAL APPARATUS AND TEST CONDITIONS}

A high pressure and low temperature triaxial test system has been self-designed both by CNOOC Research Institute and Dalian University of Technology, as shown in Figure 1. The triaxial test system allows axial loading, confining pressure, temperature control through a computer control system. A confining pressure up to $30 \mathrm{MPa}$ can be applied through a high pressure pump. The temperature of the pressure chamber can be adjusted from $-30^{\circ} \mathrm{C}$ to $25^{\circ} \mathrm{C}$ by a controllable constant temperature bath and heat exchangers. The axial loading frame can apply a maximum permissible load of $600 \mathrm{kN}$. Two different kinds of hydrate dissociation methods which are depressurization and thermal stimulation methods can be carried out in this experimental system.

The hydrate is artificially manufactured using methane and ice powder mixed in a reactor, and then the hydrate-ice mixture is mixed with the host material of kaolin clay before the hydrate-bearing sediment specimen is formed in a special reactor by "compression method". The parameters of the specimen are listed in Table 1. Specimen preparation were carried out in a cold storage room (about $-15^{\circ} \mathrm{C}$ ).

Depressurization and thermal stimulation are used to induce hydrate dissociation. Three parameters relevant to the behavior of hydrate dissociation are investigated, including: (1) effects of dissociation time; (2) effects of confining pressure; and (3) effects of dissociation temperature. According to permafrost and

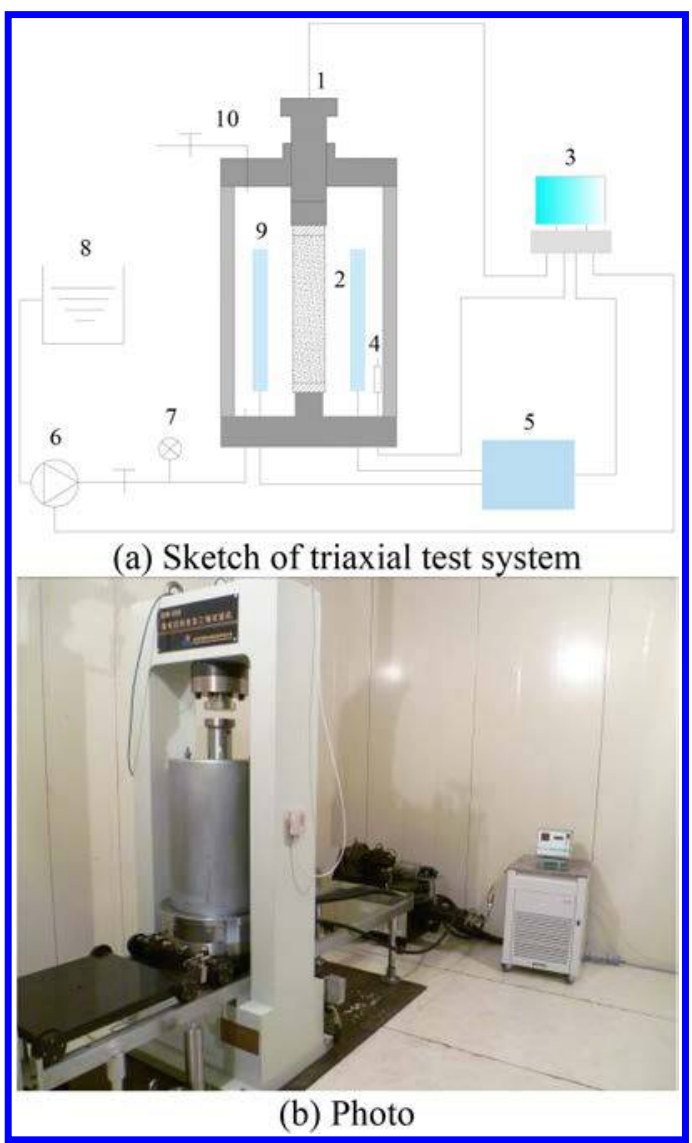

Figure 1. Triaxial test system. 1-load cell, 2-specimen, 3-computer control system, 4-thermocouple, 5-constant temperature bath, 6-high-pressure pump, 7-pressure gauge, 8-oil tank, 9-heat exchanger, 10-air pressure line.

Table 1. Parameters of specimen.

\begin{tabular}{ll}
\hline Name & Value \\
\hline Size of specimen $(\mathrm{mm})$ & $\Phi 61.8 \times 125$ \\
Volume of specimen $\left(\mathrm{cm}^{3}\right)$ & 374.95 \\
Porosity $(\%)$ & 43 \\
Saturation of methane hydrate $(\%)$ & $25-30$ \\
Mass of kaolin clay $(\mathrm{g})$ & 556 \\
Mass of hydrate-ice mixture $(\mathrm{g})$ & 147 \\
Density of specimen $\left(\mathrm{g} / \mathrm{cm}^{3}\right)$ & 1.875 \\
Dry density of specimen $\left(\mathrm{g} / \mathrm{cm}^{3}\right)$ & 1.483 \\
\hline
\end{tabular}

ocean environmental conditions, in the consolidated undrained $(\mathrm{CU})$ triaxial test, the sample is consolidated under different confining pressures in response to different hydrate burial depths; the experimental temperature is varied from $-5^{\circ} \mathrm{C}$ to $5^{\circ} \mathrm{C}$ in accordance with the frozen soil and seabed temperatures. The consolidation time is set as 2 hours and the shearing rate of $1 \% / \mathrm{min}$ is adopted for all tests. Test cases are listed 
Table 2. Cases for hydrate dissociation triaxial tests.

\begin{tabular}{|c|c|c|c|}
\hline Case & $\begin{array}{l}\text { Confining } \\
\text { pressure (MPa) }\end{array}$ & $\begin{array}{l}\text { Dissociation } \\
\text { time (h) }\end{array}$ & $\begin{array}{l}\text { Dissociation } \\
\text { temperature }\left({ }^{\circ} \mathrm{C}\right)\end{array}$ \\
\hline 1 & 2 & $\begin{array}{r}0 \\
6 \\
24 \\
48\end{array}$ & -5 \\
\hline 2 & 1 & $\begin{array}{r}0 \\
6 \\
24 \\
48\end{array}$ & \\
\hline 3 & 0.5 & $\begin{array}{r}0 \\
6 \\
24 \\
48\end{array}$ & \\
\hline Case & $\begin{array}{l}\text { Dissociation } \\
\text { time }(\mathrm{h})\end{array}$ & $\begin{array}{l}\text { Dissociation } \\
\text { temperature }\left({ }^{\circ} \mathrm{C}\right)\end{array}$ & $\begin{array}{l}\text { Confining } \\
\text { pressure }(\mathrm{MPa})\end{array}$ \\
\hline 4 & 0 & $\begin{array}{r}-5 \\
0 \\
5\end{array}$ & 1 \\
\hline 5 & 6 & $\begin{array}{r}-5 \\
0 \\
5\end{array}$ & \\
\hline 6 & 24 & $\begin{array}{r}-5 \\
0 \\
5\end{array}$ & \\
\hline
\end{tabular}

in Table 2. It is noted that the dissociation time equal to 0 hour means the hydrate is at the stable state.

\section{RESULTS AND DISCUSSIONS}

\subsection{Effects of dissociation time}

In the cases listed in the top part of Table 2, the temperature is $-5^{\circ} \mathrm{C}$, and the sample is under an atmospheric pressure (nearly $100 \mathrm{kPa}$ ) which is obviously lower than the equilibrium pressure, thus the hydrate dissociation continues. Under the depressurization condition, the effects of dissociation time on the shear behavior of hydrate-bearing specimens are investigated. Figure 2 shows the deviator stress (denoted as $\sigma_{1}-\sigma_{3}$ ) and axial strain (denoted as $\varepsilon$ ) behavior under the same confining pressure and temperature subjected to the dissociation time equals to $0 \mathrm{~h}, 6 \mathrm{~h}, 24 \mathrm{~h}$ and $48 \mathrm{~h}$, respectively. It is indicated that the deviator stress increases gradually with increasing axial strain and finally reaches a constant value with a reasonably asymptotic behavior. The gas generated from hydrate dissociation will result in the increasing excess pore pressure, and in undrained condition, once the excess pore pressure is higher than the confining pressure due to a large amount of hydrate dissociation, the sample will reach failure. The specimen shows a strain hardening behavior up to the end of the testing when the axial strain is more than $15 \%$. Because there is no obvious peak deviator stress in the stress-strain curves, the

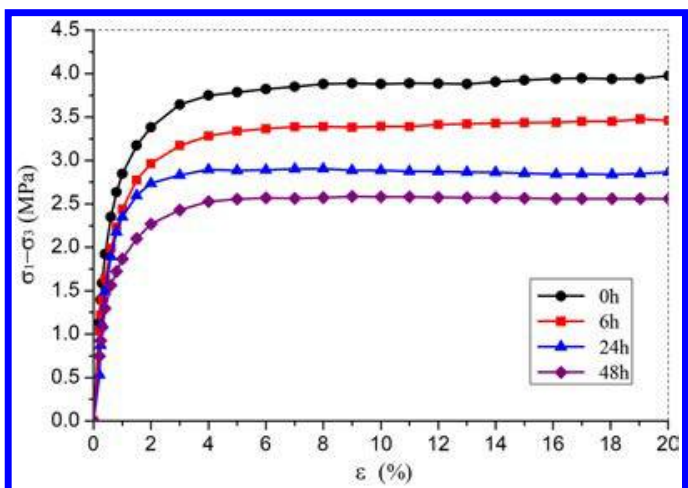

(a) Case 1

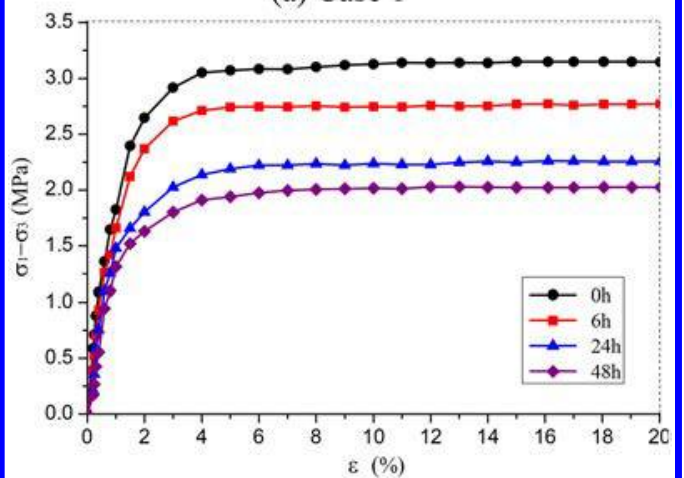

(b) Case 2

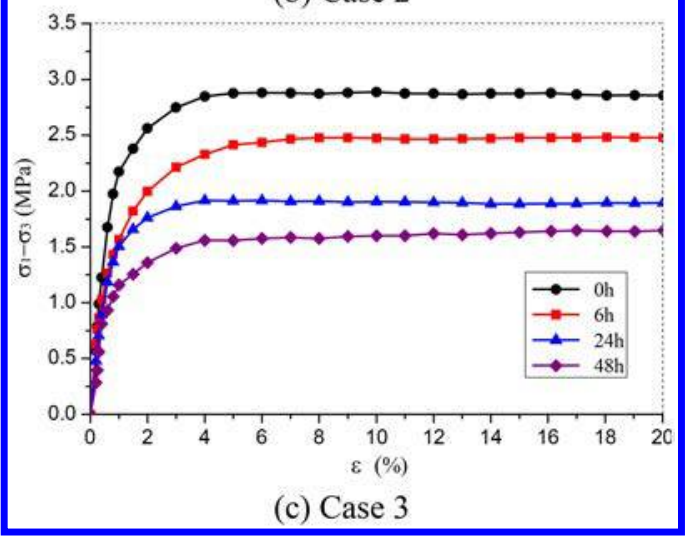

Figure 2. Effects of dissociation time on shear behaviors of hydrate-bearing kaolin clay.

maximum deviator stress corresponds to $15 \%$ axial strain.

It is concluded that at the same confining pressure and temperature, the longer dissociation time will result in increased amount of dissociated hydrate corresponding to marked decrease of shear strength. Hydrate dissociation may destroy the sediment structure and soil particle cementation resulting in sample fracture. Due to the gas generated from hydrate dissociation, the increase in excess pore pressure will result in the reductions of both effective stress and shear strength of hydrate-bearing sediment. Although 
Table 3. Hydrate dissociation by depressurization.

\begin{tabular}{lllll}
\hline & $\begin{array}{l}\text { Confining } \\
\text { pressure } \\
\text { Case } \\
(\mathrm{MPa})\end{array}$ & $\begin{array}{l}\text { Dissociation } \\
\text { time } \\
(\mathrm{h})\end{array}$ & $\begin{array}{l}\text { Maximum } \\
\text { deviator } \\
\text { stress }(\mathrm{MPa})\end{array}$ & $\begin{array}{l}\text { Relative } \\
\text { reductions } \\
(\%)\end{array}$ \\
\hline 1 & 2 & 0 & 3.925 & - \\
& & 6 & 3.435 & 12.5 \\
& & 24 & 2.855 & 27.3 \\
& & 48 & 2.567 & 34.6 \\
2 & 1 & 0 & 3.149 & - \\
& & 6 & 2.768 & 12.1 \\
& & 24 & 2.250 & 28.5 \\
& & 48 & 2.023 & 35.8 \\
& & 0 & 2.893 & - \\
& 0.5 & 6 & 2.476 & 14.4 \\
& & 24 & 1.886 & 34.6 \\
& & 48 & 1.631 & 43.7 \\
\hline
\end{tabular}

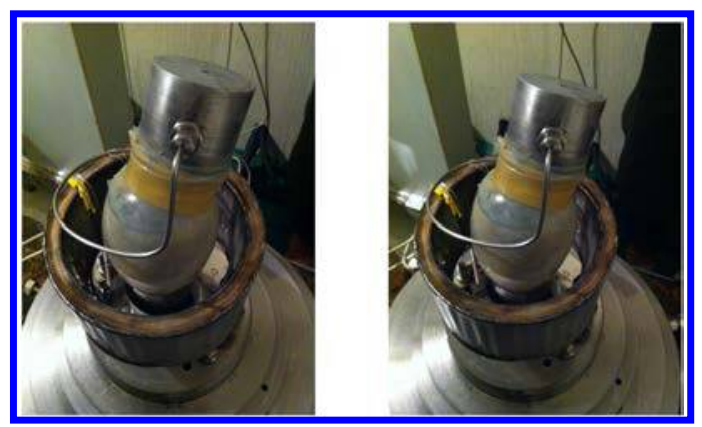

Figure 3. Specimen after experiments by depressurization.

the axial strain of $15 \%$ is exceeded in most tests, high residual strengths are observed because the water from hydrate dissociation may freeze under $-5^{\circ} \mathrm{C}$. The detailed measurement results of the present cases are listed in Table 3. Compared with the stable state of hydrate, the analysis demonstrates that the relative reductions of the maximum deviator stresses are $12.1 \%-14.4 \%$ for $6 \mathrm{~h}, 27.3 \%-34.6 \%$ for $24 \mathrm{~h}$ and $34.6 \%-43.7 \%$ for $48 \mathrm{~h}$, respectively. It implies that the shear strength reduces near to $50 \%$ when the hydrate dissociation time is close to $48 \mathrm{~h}$. After experiments, the specimen is recorded as shown in Figure 3. Highlighting a large amount of methane has been released from the dissociating hydrates, and the gas pressure is more than the atmospheric pressure.

\subsection{Effects of confining pressure}

The effects of confining pressure on the shear behavior of hydrate-bearing specimens are examined under the same dissociation time and temperature (Table 2). As reported in Table 3, at confining pressures between $2 \mathrm{MPa}$ and $0.5 \mathrm{MPa}$, the relative reductions in the maximum deviator stresses can be calculated as $26.8 \%$, $27.9 \%, 33.9 \%$ and $36.5 \%$ for the dissociation time equals to $0 \mathrm{~h}, 6 \mathrm{~h}, 24 \mathrm{~h}$ and $48 \mathrm{~h}$, respectively. It is

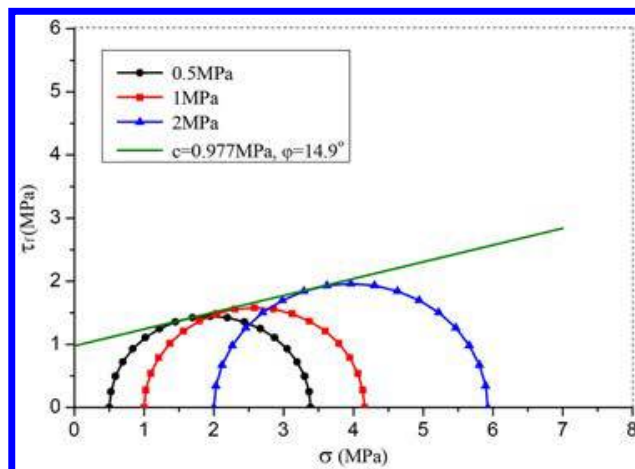

(a) Dissociation time equals to $0 \mathrm{~h}$

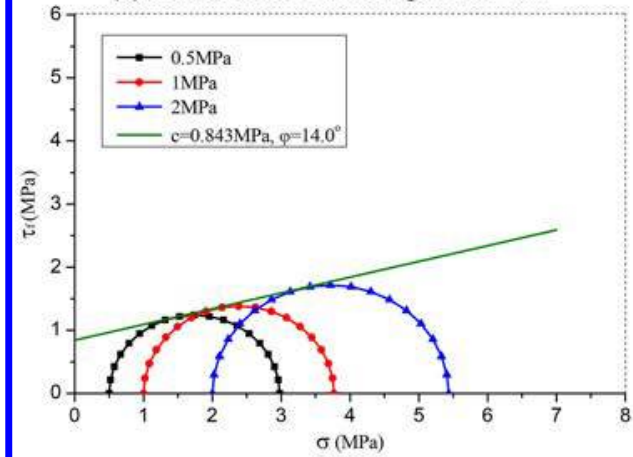

(b) Dissociation time equals to $6 \mathrm{~h}$

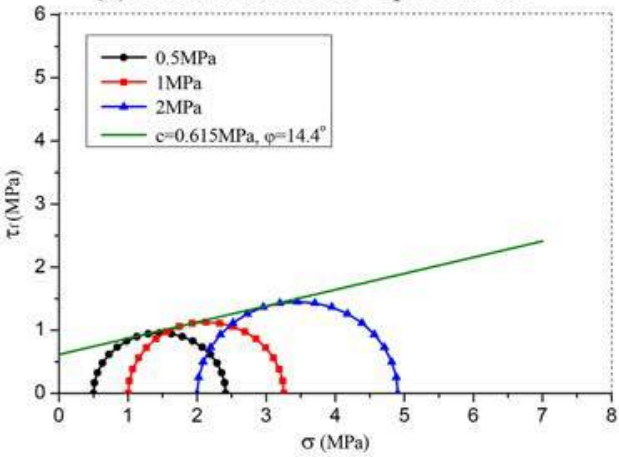

(c) Dissociation time equals to $24 \mathrm{~h}$

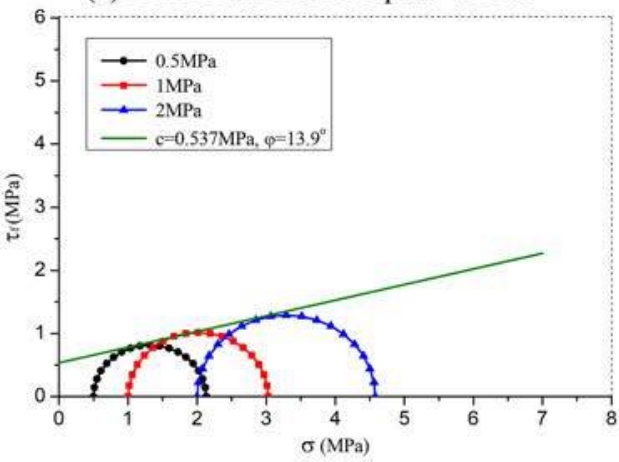

(d) Dissociation time equals to $48 \mathrm{~h}$

Figure 4. Mohr's envelopes of methane hydrate-bearing sediment at different dissociation times. 


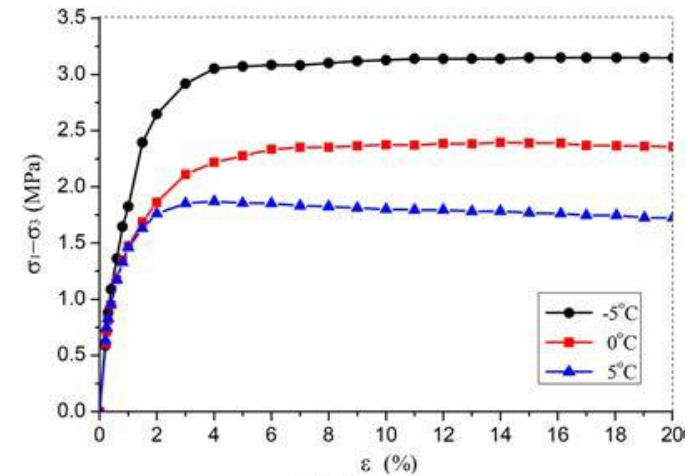

(a) Case 4

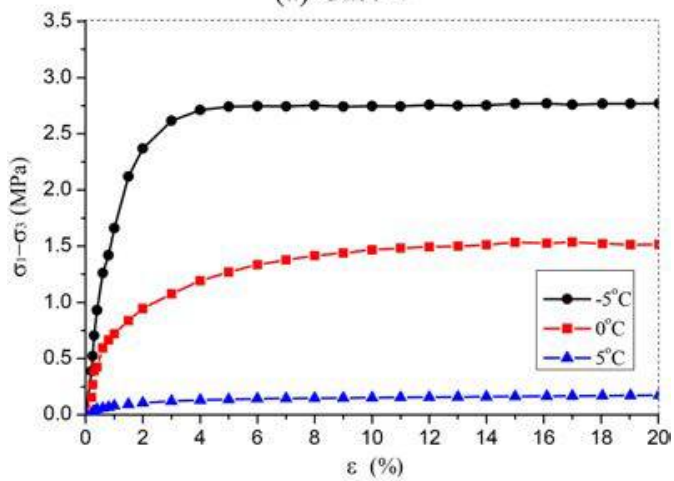

(b) Case 5

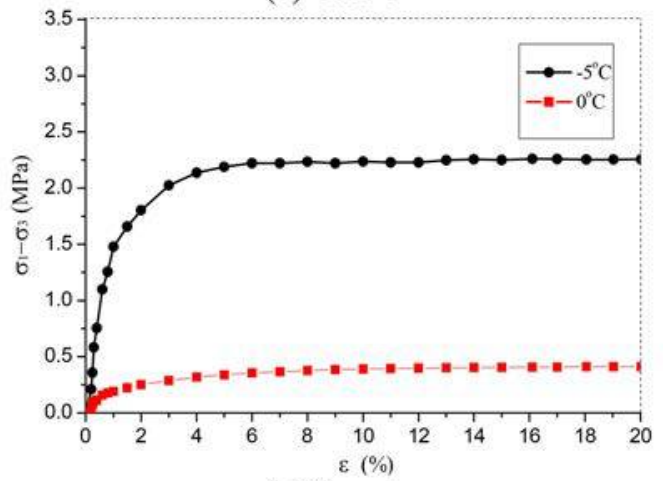

(c) Case 6

Figure 5. Effects of dissociation temperature on shear behaviors of hydrate-bearing kaolin clay.

demonstrated that at shallower hydrate burial depth, namely a lower confining pressure, measured shear strength is significantly influenced by hydrate dissociation. Figure 4 depicts the Mohr's circles and envelopes of hydrate-bearing sediment at different dissociation times, with the calculated internal friction angle and cohesion of the specimens. It can be seen that cohesion decreases from $0.977 \mathrm{MPa}$ to $0.537 \mathrm{MPa}$, a reduction is near to $45 \%$ with the increasing dissociation time, but the internal friction angle is little changed and fluctuates within $1^{\circ} \mathrm{C}$.
Table 4. ydrate dissociation by thermal stimulation.

\begin{tabular}{lllll}
\hline & $\begin{array}{l}\text { Dissociation } \\
\text { time } \\
\text { Case }\end{array}$ & $\begin{array}{l}\text { Dissociation } \\
\text { temperature } \\
\left({ }^{\circ} \mathrm{C}\right)\end{array}$ & $\begin{array}{l}\text { Maximum } \\
\text { deviator } \\
\text { stress }(\mathrm{MPa})\end{array}$ & $\begin{array}{l}\text { Relative } \\
\text { reductions } \\
(\%)\end{array}$ \\
\hline 4 & 0 & -5 & 3.149 & - \\
& & 0 & 2.387 & 24.2 \\
& & 5 & 1.769 & 43.8 \\
5 & 6 & -5 & 2.768 & - \\
& & 0 & 1.535 & 44.5 \\
6 & \multirow{2}{*}{24} & 5 & 0.163 & 94.1 \\
& & -5 & 2.250 & - \\
& & 0 & 0.404 & 82.0 \\
& & 5 & - & - \\
\hline
\end{tabular}

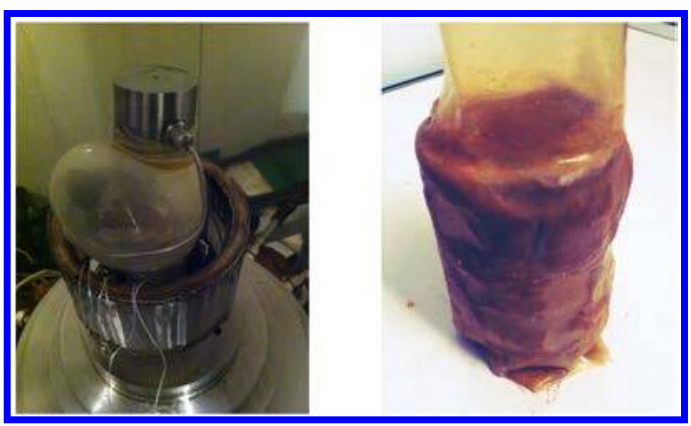

Figure 6. Specimen after experiments by thermal stimulation.

\subsection{Effects of dissociation temperature}

The thermal stimulation method is adopted to induce dissociation by adjusting the temperature of the pressure chamber, through the constant temperature bath and heat exchangers. The test parameters for these tests are listed in the bottom part of Table 2. Figure 5 considers the effects of dissociation temperature on shear behavior of hydrate-bearing specimens. As shown in Figure 5(c), for Case 6 under the confining pressure $(1 \mathrm{MPa})$ and dissociation time $(24 \mathrm{~h})$, the hydrate dissociation resulted in a nearly complete loss of strength (deviator stress near to $0 \mathrm{MPa}$ ). Thus, the stress-strain curve of $5^{\circ} \mathrm{C}$ is not shown in Figure 5(c).

From Figure 5(a)-5(c), it is concluded that in Cases 4-6, the maximum deviator stress decreases as the temperature increases. For the temperature of below $0^{\circ} \mathrm{C}\left(-5^{\circ} \mathrm{C}\right.$ and $\left.0^{\circ} \mathrm{C}\right)$, it is mainly because different types of particle bonding between the sediment and hydrate are generated under different temperatures; for the temperature of above $0^{\circ} \mathrm{C}\left(0^{\circ} \mathrm{C}\right.$ and $\left.5^{\circ} \mathrm{C}\right)$, the strength reduction is probably because the hydrate dissociation and ice melting. It can be seen in Table 4, that the maximum deviator stress reduces significantly from $24.2 \%$ to $94.1 \%$ with increasing temperatures. Compared to the depressurization method, the dissociation rate of thermal stimulation is higher with larger amounts of dissociating hydrate as well as more apparent strength degradation. The specimen for Case 6 is presented in Figure 6, showing the expansion of the 
rubber membrane and the specimen reduced near to an ooze mud.

\section{CONCLUSIONS}

A series of experiments were performed by a triaxial test system in order to study the influence of gas hydrate dissociation on the mechanical properties of gas hydrate-bearing sediment. Based on the results, the following conclusions can be drawn.

(1) Under the same confining pressure and temperature, longer dissociation times result in larger amounts of hydrate dissociation, with a corresponding reduction in shear strength: shear strength reduces are near to $50 \%$ for the $48 \mathrm{~h}$ hydrate dissociation time.

(2) At the same dissociation time and temperature, the shallower hydrate burial depth, namely the lower confining pressure, may be more significantly influenced by hydrate dissociation. It can be seen that cohesion decreases from $0.977 \mathrm{MPa}$ to $0.537 \mathrm{MPa}$ with the reduction near to $45 \%$, but the internal friction angle is little changed and fluctuates within $1^{\circ} \mathrm{C}$.

(3) Temperature has an effect on the strength of hydrate-bearing sediment. Different types of particle bonding between the sediment and hydrate are generated under different temperatures; if the temperature is above $0^{\circ} \mathrm{C}$, the strength reduction is probably because the hydrate dissociation and ice melting.

\section{ACKNOWLEDGMENTS}

Financial support from the National Science and Technology Major Project (Grant nos. 2011ZX05056-002 and 2011ZX05026-004) is greatly acknowledged. The authors would also like to thank the help of many colleagues for their generous help with the experiments.

\section{REFERENCES}

Davies, R., Cartwright, J. \& Rana, J. 1999. Giant hummocks in deepwater marine sediments: Evidence for large-scale differential compaction and density inversion during early burial. Geology 27(10): 907-910.

Dickens, G.R., O’Neil, J.R., Rea, D.K. \& Owen, R.M. 1995. Dissociation of oceanic methane hydrates as a cause of the carbon isotope excursion at the end of the Paleocene. Paleoceanography 10(6): 965-971.

Dillon, W., Nealon, J.W., Taylor, M.H., Lee, M.W., Drury, R.M. \& Anton, C.H. 2001. Seafloor collapse and methane venting associated with gas hydrate on the Blake Ridge: Causes and implications to seafloor stability and methane release. Washington DC: American Geophysical Union.

Field, M.E. 1990. Submarine landslides associated with shallow seafloor gas and gas hydrates off northern California. AAPG Bulletin 74(6): 971-972.

Grozic, J.L.H. \& Kvalstad, T.K. 2001. Effect of gas on deepwater marine sediments. In D.J. White, W.A. Take, M.D.
Bolton \& S.E. Munachen (eds), Proc. 15th Int. Conf. Soil Mech. Geotech. Eng., Istanbul, 19-23 August 2001. Leiden: Swets \& Zeitlinger.

Hyodo, M., Nakata, Y., Yoshimoto, N., Orense, R. \& Yoneda J. 2009. Bonding strength by methane hydrate formed among sand particles. In M. Nakagawa \& S. Luding (eds.), Powders and Grains; Proc. 6th Int. Conf. Micromech. Granular Media, Colorado, 13-17 July 2009. Melville: American Institute of Physics.

Kayen, R.E. \& Lee, H.J. 1991. Pleistocene slope instability of gas hydrate-laden sediment on the Beaufort Sea margin. Marine Geotechnology 10(1-2): 125-141.

Kennett, J.P. \& Fackler-Adams, B.N. 2000. Relationship of clathrate instability to sediment deformation in the upper Neogene of California. Geology 28(3): 215-218.

Kennett, J.P., Cannariato, K.G., Hendy, I.L. \& Behl, R.J. 2003. Methane hydrates in quaternary climate change: The clathrate gun hypothesis. Washington DC: American Geophysical Union.

MacDonald, G.J. 1990. Role of methane clathrates in past and future climates. Climatic Change 16(2): 247-281.

Mienert, J., Vanneste, M., Bünz, S., Andreassen, K., Haflidason, H. \& Sejrup, H.P. 2005. Ocean warming and gas hydrate stability on the mid-Norwegian margin at the Storegga slide. Marine and Petroleum Geology 22(1-2): 233-244.

Mikami, J., Masuda, Y., Uchida, T., Satoh, T. \& Takeda, H. 2006. Dissociation of natural gas hydrate observed by Xray CT scanner. Annals New York Academy of Sciences 912(1): 1011-1020.

Nisbet, E.G. 1990. The end of the ice-age. Canadian Journal of Earth Sciences 27(1): 148-157.

Paull, C.K., Buelow, W.J., Ussler, W. \& Borowski, W.S. 1996. Increased continental-margin slumping frequency during sea-level lowstands above gas hydrate-bearing sediments. Geology 24(2): 143-146.

Rothwell, R.G., Thomson, J. \& Kahler, 1998. Low-sealevel emplacement of a very large Late Pleistocene 'megaturbidite' in the western Mediterranean Sea. Nature 392(6674): 377-380.

Van Rensbergen, P., De Batist, M., Klerkx, J., Hus, R., Poort, J., Vanneste, M., Granin, N., Khlystov, O. \& Krinitsky, P. 2002. Sublacustrine mud volcanoes and methane seeps caused by dissociation of gas hydrates in Lake Baikal. Geology 30(7): 631-634.

Vogt, P.R., Crane, K., Sundvor, E., Max, M.D. \& Pfirman, S.L. 1994. Methane-generated(?) pockmarks on young, thickly sedimented oceanic crust in the Arctic: Vestnesa ridge, Fram strait. Geology 22(3): 255-258.

Vogt, P.R., Gardner, J. \& Crane, K. 1999. The NorwegianBarents-Svalbard (NBS) continental margin: Introducing a natural laboratory of mass wasting, hydrates, and ascent of sediment, pore water, and methane. Geo-Marine Letters 19(1/2): 2-21.

Zhang, X.H., Lu, X.B., Wang, S.Y. \& Li, Q.P. 2011. Experimental study of static and dynamic properties of tetrahydrofuran hydrate-bearing sediments. Rock and Soil Mechanics 32(1): 303-308.

Zhou, X.T., Fan, S.S., Liang, D.Q., Guan, J.A. \& Tang, C.P. 2007. Experimental research on the decomposition of methane hydrate by depressurization in quartz sands. Natural Gas Chemical Industry 32(1): 52-55.

Zuhlsdorff, L. \& Spiess, V. 2004. Three-dimensional seismic characterization of a venting site reveals compelling indications of natural hydraulic fracturing. Geology 32(2): 101-104. 